\title{
EFFECT OF SOME INSECTICIDES ON APHID INSECT MYZUS PERSICAE (Sulzer) AND IT'S PREDATORS AND PARASITES
}

\author{
Juhina Adrees Mohammed Ali \\ Department of Plant Protection, College of Agriculture and Forestry, University of \\ Mosul \\ E.mail: Juhina1234@yahoo.com
}

\begin{abstract}
Present study aimed to determine the effects of three insecticides which were Actara, Match and Nimex on Myzuspersicae (Sulzer) and on it's both parasite Aphidiusmatricariae Halidayand predators Coccinellaseptempunctata L. and CoccinellanovemnotataHerbst. Results showed that all three insecticides effected parasitic efficiency, of Aphidiusmatricariaeand Nimex recorded highest mortality rate on Myzuspersicae (Sulzer) which was 98-73. All three used pesticides (Actara, Match and Nimex) affected predatory and parasitic efficiency after direct exposure, while less effects the same pesticides on predator efficiency of both C.septempunctata and C. novemnotata have been recorded after indirect treatment. Keywords: Coccinellaseptempunctata L. and CoccinellanovemnotataHerbst. Insecticides( Actara, Match and Nimex)

Received/ / 2019 Accepted, / /2020

\section{INTRODUCTION}

The use of selective pesticides andsafe methods which specific only there target (pest)doesn't affect to natural enemies that highly efficient in reducing the number of prey specially aphids and other insect families that important to the biological control such as Coccinelled, including CoccinellaseptempunctataL., seven- spotted ladybird, and nine- spotted ladybird Coccinellanovemnotataherbst(Al-Mallah, and Al-Mikhlafi, 2005). Pesticide such as trigard has direct impact on aphids and reduce it is number without affecting the efficiency of their biological enemies(Al-Mallah and Ali,2007).

According to the previous study by Abdel-Wali,et al.(2007), which reported that $0.5 \%$ concentration of trigard had a fatal effect on seven- spotted ladybird, in mean of 47.3 and 43 insect for both male and femalerespectively. Many insecticidesuch as Sumicidin, Abamectin, Pirimicarb and Actara have been used against insect pest of peach specially Aphids which attacks 44 plant families(Palumbo, 2011).

However, other investigation proved that pesticide like trigard not affected the predatory efficiency of Coccinellanovemnotata and parasitic efficiency of Aphidiusmatricariae (Fuentes-Contreras et al.,2007andSaljoqi and Van Emdem,2003).Actara pesticide which is derived from Benzoylphenylurea, considered as systemic insecticide it affects acetylcholine receptors in the central nervous system of insects(Silva et al., 2012).
\end{abstract}


Recently, Botanical insecticides or plant extracts such as neem oil have been shown to be very effective against insects in many ways, the ingestion of green pesticides by insect cause death, however they are harmless for human( Silva et al., 2012). The mode of action of Botanical pesticide have been explained byBaozhuZhong et al.(2017) and Fuentes-Contreraset al.(2007), that neem oil causes hormonal imbalance which prevent larval growth and cause death. Additionally,larvicidal effects of neem oil has been recorded against more than 200 insect species, also azadirachinewhich can be extracted from neem tree showed larvicidal activity by 60 to $70 \%$ after 3 to 14From treatment days(Palumbo et al., 2008).Secondary plant product such as tetranortriterpenoid from neem leaves or seeds has bitter test which inhibit juvenile hormone in insect and result in death of insect from all stages of their (larvae, pupae and nymphs), thus, immune system of insect cannot response(Zanuncioet a., 2016).

\section{MATERIALS AND METHODS}

The present study was conducted during 2018_2017 at the department of Plant Protection - Faculty of Agriculture and Forestry University of Mosul, the investigation carried out under controlled laboratory condition (at an average temperature of $20 \pm 5^{\circ} \mathrm{C}$ and relative humidity $45 \pm 5 \%$. This study includes the following points:

First: Insect Breeding

The different life stages of the Spotted ladybirdCoccinellaseptempunctata and Spotted ladybirdCoccinellanovemnotata predator were collected from infected potato fields. The eggs(over 350 eggs) were kept in sterile plastic petri-dishes with a diameter of $9 \mathrm{~cm}$ and observed daily until hatching while larvae and adults were isolated in small breeding cages $(10 \times 20 \times 15 \mathrm{~cm})$ and provided with leaves of infected potato with aphids. Specialized cages have been used for the collection of aphids Myzuspersicafrom untreated field with pesticide for more than one season. All samples (ladybirds,aphids and parasite ) were sent for diagnosis at the Museum of Natural History in Baghdad.

Second: use of three insecticides against aphid insects:

Three different insecticides have been used against aphid insects, each with labeling recommended concentration which were Actara, Match and Nimexat concentration of $0.5,0.4,0.5 \%$, respectively. Five replications of each concentrationwere used for increased the rate of accuracy, each concentration prepared in $2 \mathrm{mlwhile}$ the control treatment was sprayed with $2 \mathrm{ml}$ of distal water, each treatmentincluded one refined 20 immature insect and placed on leafs of plant in a Petri dish was treated using 2 mlwhile the control treatment was sprayed with 2 $\mathrm{ml}$ of distal water. Finally, all readings recorded after 24 hours of incubation under laboratorycontrolled condition and results corrected by Abbott (1925). Third: Effects of three different pesticide according different treatment methods on aphid insects. 
Table (1):Three used pesticide each with it is active ingredients and origins.

\begin{tabular}{|c|c|c|c|}
\hline Insecticides & $\begin{array}{c}\text { Manufactured } \\
\text { company }\end{array}$ & Groups & Active ingredients \\
\hline Actara & Syngenta & Neonicatinoid & Thiamethoram 25/wg \\
\hline Match & $\begin{array}{c}\text { Syngenta } \\
\text { switzerland }\end{array}$ & Benzoyalphenylurean & Lufenuron $5 \%$ \\
\hline Nimex & $\begin{array}{l}\text { JiangsRotam } \\
\text { chemistry }\end{array}$ & $\begin{array}{l}\text { Neem derived } \\
\text { product }\end{array}$ & Azadiractin $4.5 \mathrm{G} / \mathrm{L}$ \\
\hline
\end{tabular}

Three different types of treatment have been used for each pesticide Actara, Match and Nimex each with it is recommended concentration 0.05, 0.04, 0.05 $\mathrm{m} / 1 \mathrm{~L}$, respectively. In order to determine the best efficiency, first treatment included leaf plant, second treatment included leaf plant with the aphids and third treatment included sprinkles of the plant leaf with both prey and predator. Each treatment which contains 100 insects (20 in each replicate) male or female $4 \mathrm{ml}$ of pesticide prepared and hand sprayed. Five replications of each treatment increased the rate of accuracy and also for the purpose of comparison control treatment has been sprayed with $2 \mathrm{ml}$ of distal water. Finally, all readings recorded after 24 hours of incubation under laboratory controlled condition. The death rate in ladybirds male and female were calculated after 5 days of treatment and the death rates were corrected by Abbott equation, longevity and death rate have been recorded after 510 days of parasitic infections. All results recorded and corrected by Abbott (1925). The results were analyzed using completely randomized design (CRD) and the Duncan test at a $5 \%$ probability level to determined the significant differences by using SAS program.

Efficiency predator $=\frac{\text { No.Aphid.pred. }}{\text { total } N \text {. } \text {.Aphid }} \times 100$

\section{RESULTS AND DISCUSSION}

Present study aimed to determine the effects of three insecticides which were Actara, Match and Nimex on Myzuspersicaeand their natural enemies:

First: The effects of three insecticideson Myzuspersicae. According to the results in the Table (2), Nimex recorded highest mortality rate which was 98-73 and followed by Actara and Match at the range of 96-71 and 87-63, respectively.

Table (2): Effects of Actara, Match and Nimex on Myzuspersicae

\begin{tabular}{|c|c|c|}
\hline \multirow{2}{*}{ Pesticide } & \multicolumn{2}{|c|}{ Mortality\% } \\
\cline { 2 - 3 } & Mean \pm S.E & Range \\
\hline Actara & $72.16 \pm 5.7 \mathrm{C}$ & $96-71$ \\
\hline Match & $74.4 \pm 5.0 \mathrm{~B}$ & $87-63$ \\
\hline Nimex & $82.8 \pm 6.5 \mathrm{~A}$ & $98-73$ \\
\hline Control & $8.75 \pm 4.2 \mathrm{D}$ & $25-0$ \\
\hline
\end{tabular}

* Numbers under the same letter or similar letters do not have significant differences according to Duncan polynomial test at a probability level of $5 \%$. 
Second: Effect of pesticides and different treatment methods on predatory efficiency of $C$. septempunctata, $C$. novemnotata and parasitic efficiency of Aphidiusmatricariae

The effects of three treatment methods each with three insecticides for both female and male of C.septempunctata and C. novemnotata have been recorded. Results in Table (3) showed that different insecticides and treatment methods had significant effects on efficiency of predator, also present result showed the effects of different treatment methods on both male and female separately.

Table (3): Effects of Actara, Match and Nimex on predatory efficiency of $C$. septempunctata, $C$. novemnotata .

\begin{tabular}{|c|c|c|c|c|c|c|}
\hline \multirow[b]{2}{*}{ Gender } & \multirow{2}{*}{$\begin{array}{c}\text { Predators } \\
\text { Treatment } \\
\text { methods }\end{array}$} & \multirow[b]{2}{*}{ Pesticides } & \multicolumn{2}{|c|}{ C. novemnotata } & \multicolumn{2}{|c|}{ C.Septempunctata } \\
\hline & & & Mean \pm SE & Range & $\begin{array}{c}\text { Mean } \pm \\
\text { SE }\end{array}$ & Range \\
\hline \multirow{9}{*}{ Female } & \multirow{3}{*}{ First } & Actara & $83+2.7 b$ & $70-94$ & $88 \pm 3.4 b$ & $80-100$ \\
\hline & & Match & $84+3.5 b$ & $71-97$ & $98 \pm 0.22 \mathrm{a}$ & $91-100$ \\
\hline & & Nimex & $72+4.2 c$ & $65-88$ & $90 \pm 1.7 \mathrm{ab}$ & $87-100$ \\
\hline & \multirow{3}{*}{ Second } & Actara & $72+1.2 \mathrm{c}$ & $84-76$ & $88 \pm 3.2 b$ & $83-100$ \\
\hline & & Match & $65+4.2 d$ & $82-57$ & $82 \pm 3.4 b$ & $65-100$ \\
\hline & & Nimex & $72+1.2 \mathrm{c}$ & $80-65$ & $78 \pm 1.2 \mathrm{c}$ & $61-100$ \\
\hline & \multirow{3}{*}{ Third } & Actara & $57+3.1 \mathrm{f}$ & $47-70$ & $62 \pm 2.8 \mathrm{ef}$ & $52-80$ \\
\hline & & Match & $31+2.7 \mathrm{~h}$ & $45-62$ & $62 \pm 3.4 \mathrm{fg}$ & $74-45$ \\
\hline & & Nimex & $43+1.5 i$ & $39-60$ & $58 \pm 6.2 f$ & $40-61$ \\
\hline \multirow{9}{*}{ Male } & \multirow{3}{*}{ First } & Actara & $77 \pm 1.9 \mathrm{c}$ & $61-90$ & $86 \pm 4.2 b$ & $67-100$ \\
\hline & & Match & $81 \pm 1.5 b c$ & $76-88$ & $94 \pm 2.6 a$ & $84-100$ \\
\hline & & Nimex & $73+2.4 c$ & $62-79$ & $82 \pm 3.4 b$ & $65-90$ \\
\hline & \multirow{3}{*}{ Second } & Actara & $74+1.5 c$ & $63-81$ & $72+1.2 c$ & $65-92$ \\
\hline & & Match & $57+4.1 f$ & $54-68$ & $78+1.4 \mathrm{~d}$ & $62-88$ \\
\hline & & Nimex & $65 \pm 3.5 d$ & $39-72$ & $66+2.6 \mathrm{~d}$ & $41-88$ \\
\hline & \multirow{3}{*}{ Third } & Actara & $48 \pm 1.2 \mathrm{~g}$ & $34-61$ & $42 \pm 6.4 i$ & $35-67$ \\
\hline & & Match & $49+2.1 \mathrm{~g}$ & $33-56$ & $58+2.6 f$ & $47-82$ \\
\hline & & Nimex & $35+2.8 j$ & $24-52$ & $68+1.2 d$ & $60-76$ \\
\hline
\end{tabular}

* Numbers under the same letter or similar letters do not have significant differences according to Duncan polynomial test at a probability level of 5\% 
Predator efficiency according to the interaction between insecticides and sex of C.septempunctatahave been recorded regardless the methods of treatment, recorded result in male were 79.3, 77.3 and 75.3 for Actara, Match and Nimex, respectively. While recorded result in female were 66.6, 76.6 and 71 for Actara, Match and Nimex, respectively. As shown in Figure (1).

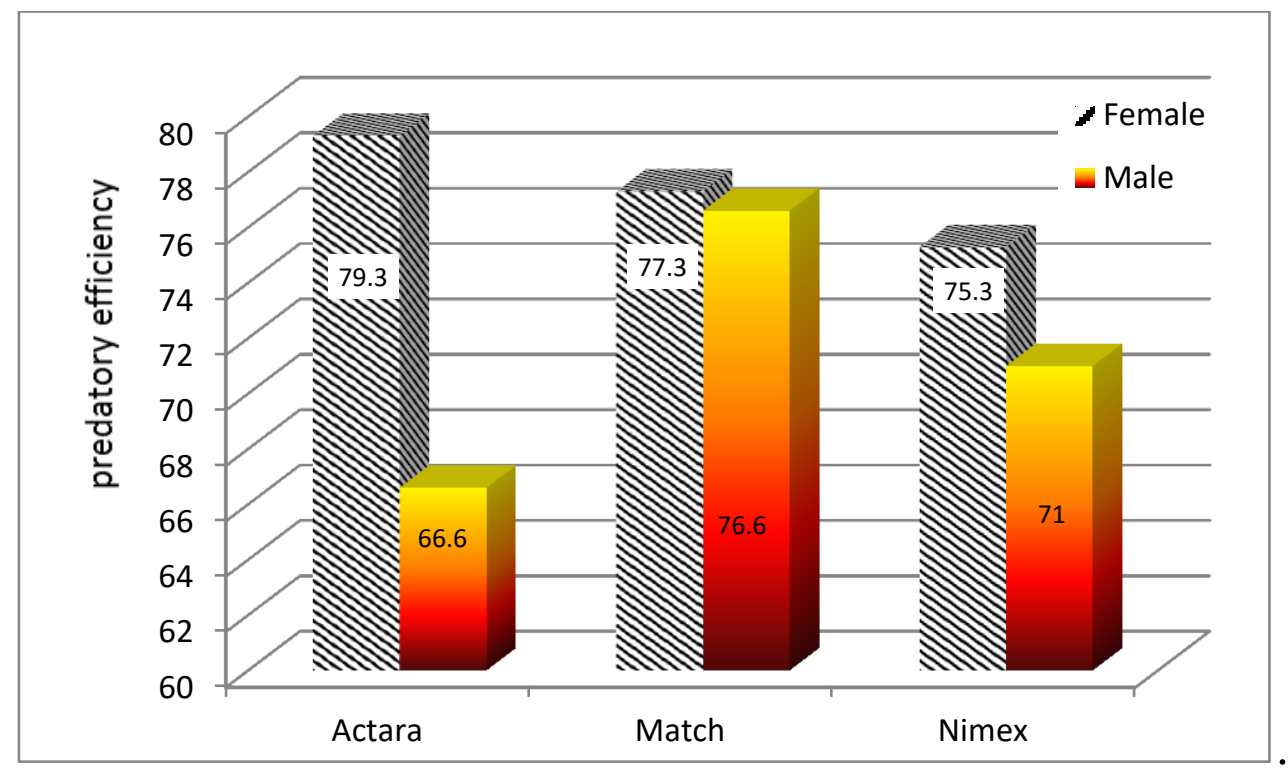

Figure(1): The effect of interference between the pesticide type and the sex of the predator regardless of the type of treatment and on the predatory efficacy of the seven point ladybird.

The recorded resultsfor all three insecticides in both male and female were so close, as shown in figure (2).

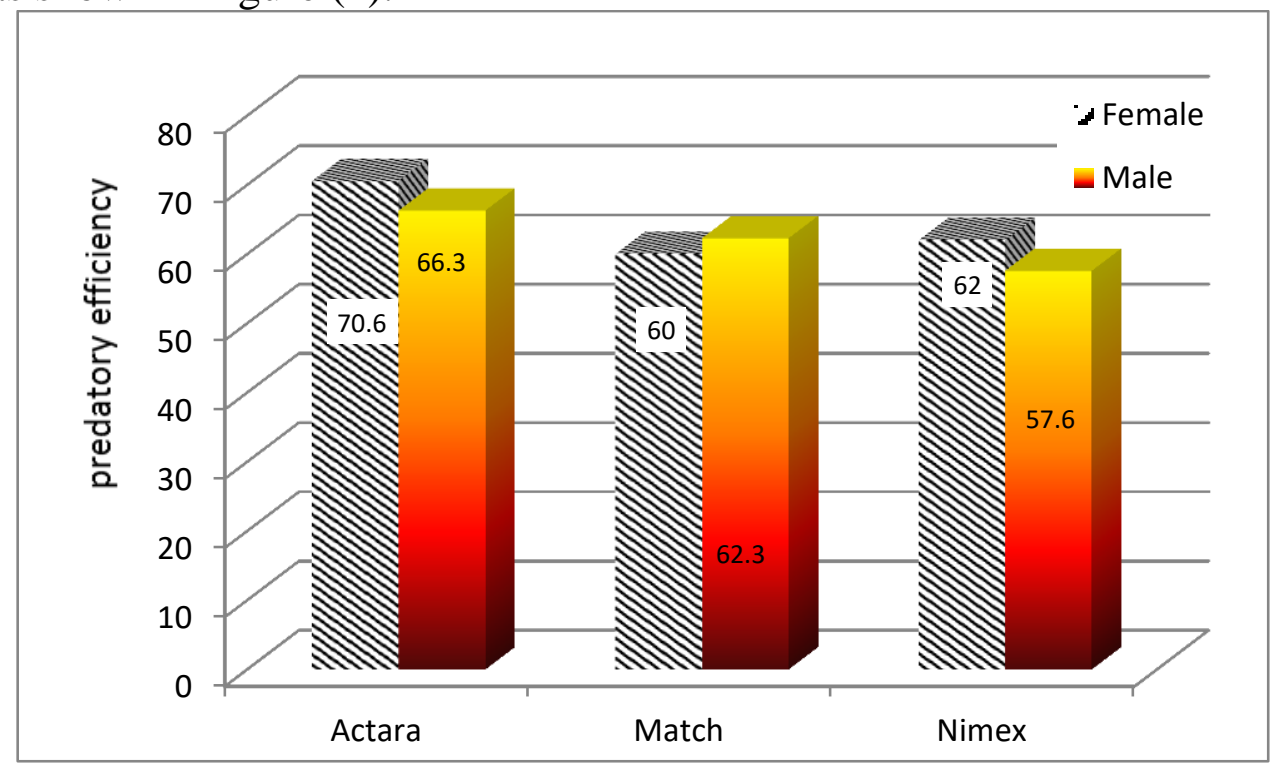

Figure (2): The effect of overlap between the pesticide type and the sex of the predator, regardless of the type of treatment, on the predatory efficiency of the ladybirdC. novemnotata.

Predator efficiency according to the interaction between treatment methods and sex of C.septempunctata have been recorded regardless to the type of insecticide, recorded result showed that all treatment affected the predator 
efficiency, however third treatment had close affected in both male and female by 56 and 57.3, respectively, as shown in figure (3).

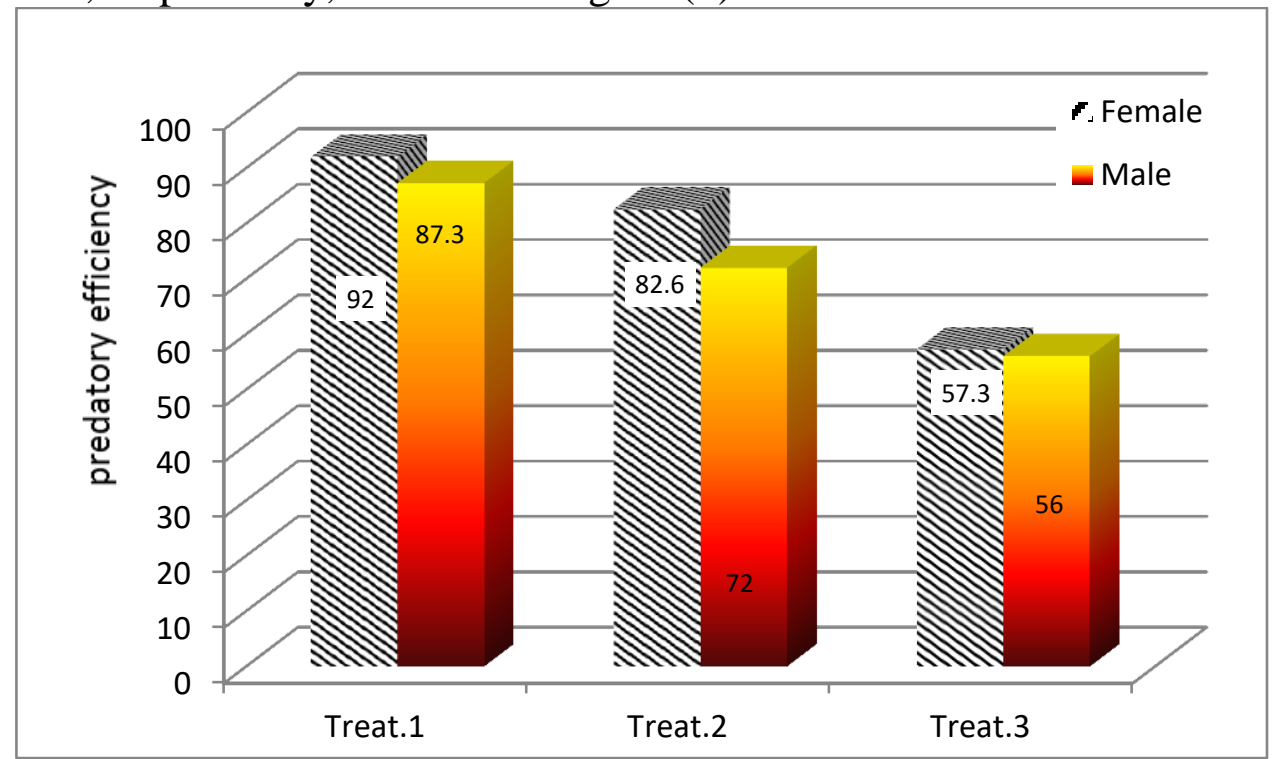

Figure( 3): The effect of interference between the type of treatment and the sex of the predator, regardless of the type of pesticide in the predatory efficiency of the ladybirdC. septempunctata.

Predator efficiency according to the interaction between treatment methods and sex of $C$. novemnotatahave been recorded regardless the type of insecticide, as showninfigure (4).

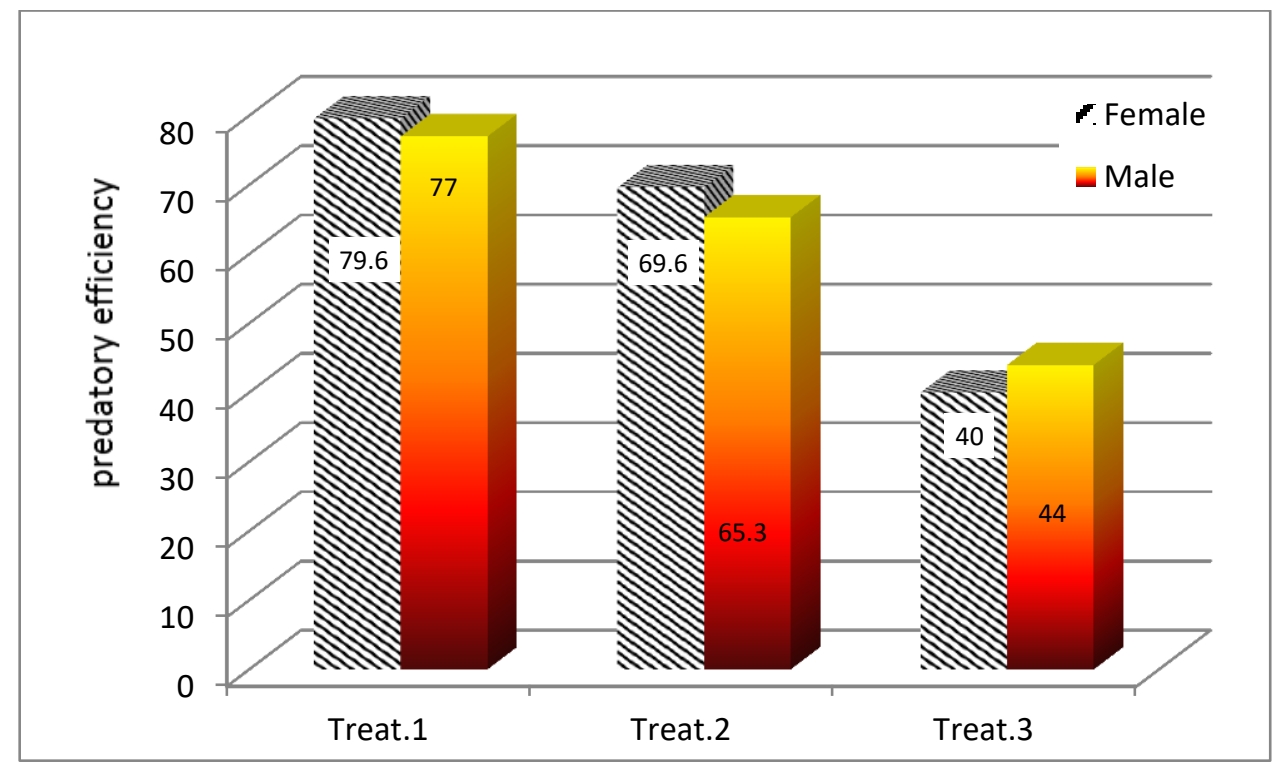

Figure (4): Effect of interference between the type of treatment and the sex of the predator, regardless of the pesticide type, in the predatory efficiency of ladybird C. novemnotata.

The results of present investigation showed that all three used pesticides (Actara, Match and Nimex) affected predatory and parasitic efficiency after direct exposure, while less effects of same pesticides on predator efficiency of both 
C.septempunctata and C. novemnotata have been recorded after indirect treatment, less affects maybe due to the feeding strategies of predator which preferred uncontaminated prey with insecticide. The highest predator efficiency in seven pointed lady bird recorded which due to the size and needs of this insect. This finding agree with previous study done by (Abdel-Waliet al., 2007 and Zanuncioet al.,2016).

The effects of three treatment methods each with three insecticides on rate of parasitic infection, longevity and killing rate of Aphidiusmatricariae have been recorded and detailed result have been shown in Table (4).

Table (4): The effects of three treatment methods each with three insecticides on rate of parasitic infection, longevity and killing rate of Aphidiusmatricariae

\begin{tabular}{|c|c|c|c|c|c|c|c|c|c|}
\hline \multirow[t]{2}{*}{ Treatment } & \multirow[t]{2}{*}{ insecticide } & \multicolumn{2}{|c|}{$\begin{array}{l}\text { Parasitic } \\
\text { efficiency }\end{array}$} & \multicolumn{2}{|c|}{ Emergent $\%$} & \multicolumn{2}{|c|}{ longevity } & \multicolumn{2}{|c|}{ killing rate\% } \\
\hline & & Mean \pm S.E & Rang & Mean \pm S.E & Rang & Mean \pm S.E & Rang & Mean \pm S.E & Rang \\
\hline \multirow{3}{*}{ First } & Actara & $89+3.8 \mathrm{~b}$ & $\begin{array}{l}60- \\
100\end{array}$ & $\begin{array}{c}16.4+0.2 \\
a\end{array}$ & $\begin{array}{l}10- \\
20\end{array}$ & $3+0.2 b$ & $1-4$ & $\begin{array}{c}34.8+0.4 \\
\mathrm{~b}\end{array}$ & $0-25$ \\
\hline & Match & $88+4.2 \mathrm{~b}$ & $\begin{array}{l}50- \\
100\end{array}$ & $\begin{array}{c}17.2+0.4 \\
a\end{array}$ & $\begin{array}{c}10- \\
18\end{array}$ & $3.2+0.2 \mathrm{a}$ & $1-4$ & $15.8+0.8 \mathrm{i}$ & $\begin{array}{c}11.1- \\
50\end{array}$ \\
\hline & Nimex & $98+1.6 \mathrm{a}$ & $\begin{array}{l}50- \\
100\end{array}$ & $\begin{array}{c}17.6+0.2 \\
a\end{array}$ & $\begin{array}{c}10- \\
18\end{array}$ & $2.4+0.2 \mathrm{c}$ & $1-3$ & $12.6+2.2 \mathrm{i}$ & $10-50$ \\
\hline \multirow{3}{*}{ second } & Actara & $45+5.1 \mathrm{f}$ & $\begin{array}{l}30- \\
75\end{array}$ & $6.8+0.8 \mathrm{e}$ & $4-12$ & $3.0+0.4 \mathrm{~b}$ & $2-4$ & $\begin{array}{c}44.6+2.4 \\
\mathrm{~d}\end{array}$ & $\begin{array}{c}33.3- \\
50\end{array}$ \\
\hline & Match & $60+1.6 \mathrm{~d}$ & $\begin{array}{c}40- \\
80 \\
\end{array}$ & $1.4+0.2 \mathrm{f}$ & $4-16$ & $2.0+0.4 \mathrm{c}$ & $1-4$ & $\begin{array}{c}55.4+0.8 \\
\mathrm{c}\end{array}$ & $\begin{array}{c}22.2- \\
100\end{array}$ \\
\hline & Nimex & $76+3.8 c$ & $\begin{array}{c}40- \\
90\end{array}$ & $\begin{array}{c}14.6+0.4 \\
b\end{array}$ & $\begin{array}{l}12- \\
18\end{array}$ & $3.0+0.2 \mathrm{~b}$ & $1-4$ & $\begin{array}{c}37.9+4.4 \\
\mathrm{e}\end{array}$ & $\begin{array}{c}33.3- \\
50\end{array}$ \\
\hline \multirow{3}{*}{ Third } & Actara & $18+2.4 \mathrm{~h}$ & $\begin{array}{l}10- \\
45\end{array}$ & $1.2+0.2 \mathrm{f}$ & $0-3$ & $3.0+0.2 \mathrm{a}$ & $2-4$ & $\begin{array}{c}76.5+1.7 \\
a\end{array}$ & $\begin{array}{c}66.3- \\
100\end{array}$ \\
\hline & Match & $39+1.2 \mathrm{~g}$ & $\begin{array}{l}20- \\
65\end{array}$ & $8.6+0.8 c$ & $4-10$ & $2.0+0.4 \mathrm{c}$ & $1-3$ & $\begin{array}{c}62.0+2.4 \\
b\end{array}$ & $70-100$ \\
\hline & Nimex & $50+0.8 c$ & $\begin{array}{c}40- \\
75 \\
\end{array}$ & $7.4+0.2 \mathrm{~d}$ & $7-12$ & $1.6+0.4 \mathrm{~d}$ & $1-3$ & $\begin{array}{c}45.4+4.3 \\
\mathrm{~d}\end{array}$ & $50-90$ \\
\hline
\end{tabular}

* Numbers under the same letter or similar letters do not have significant differences according to Duncan polynomial test at a probability level of $5 \%$.

The interaction between effects of three treatment methods and three insecticides on rate of infection, emergent rate and killing rate have been recorded and detailed result have been shown in Table (4). Results showed that first treatment method was the safest way and killing rate not exceed $23.7 \%$ which followed by second and third treatment methods. 


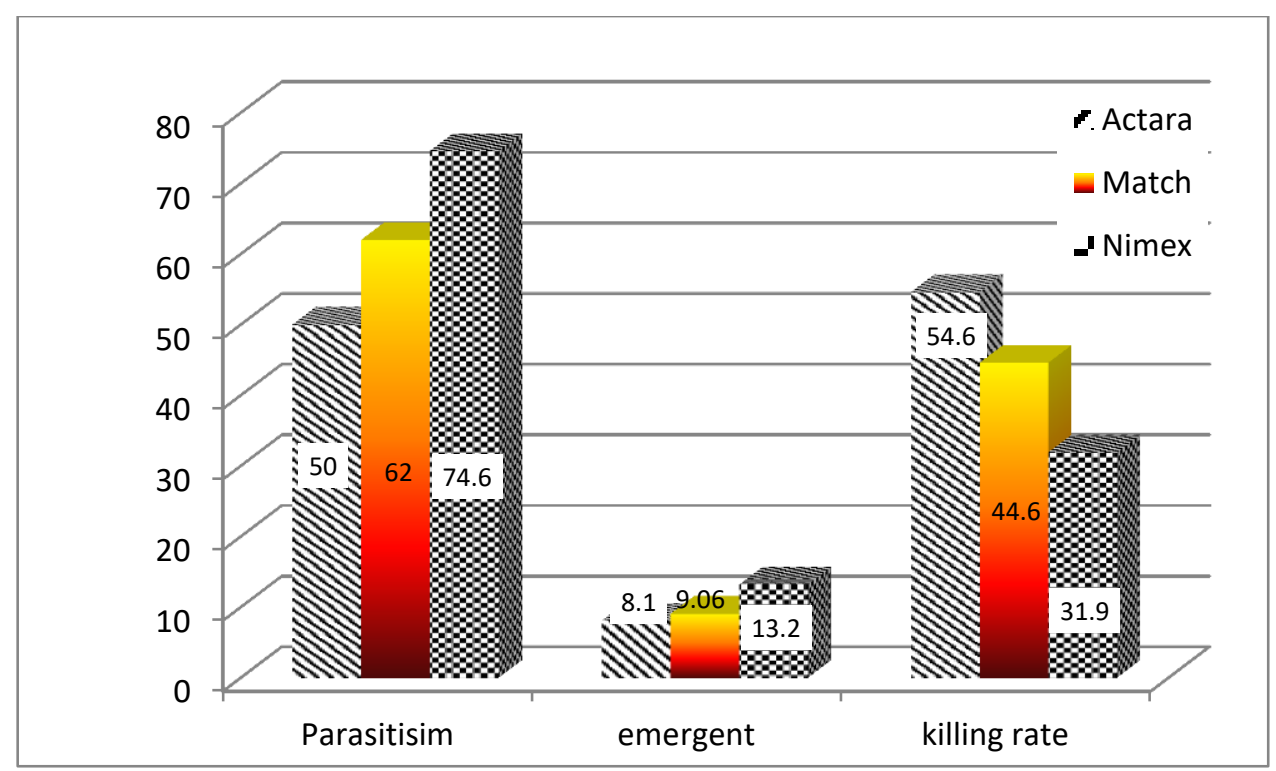

Figure (5): The effect of the interaction between the treatment with the three pesticides and their effect on the vital characteristics of the parasite from the parasitism of emerging individuals and the parasite killing rates.

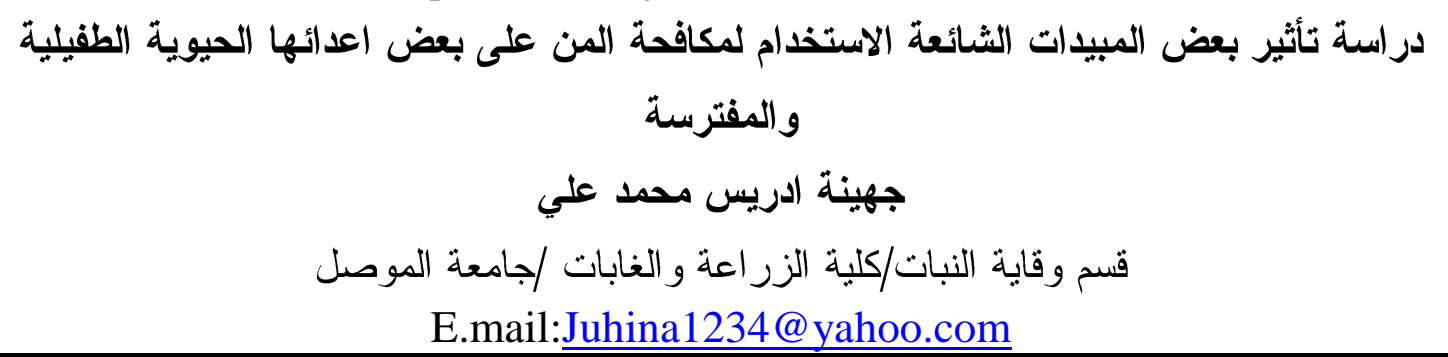

\section{الخلاصة}

هدفت الدراسة الى تحديد التأثثر لكل من مبيدات اكتار ا وماتشو ونيمكس والتي تستخدة التهدم في مكافحة

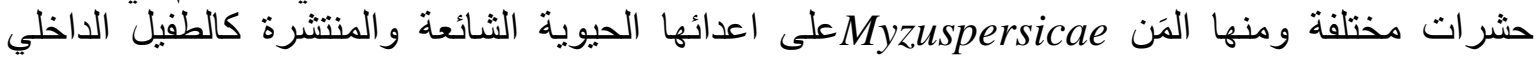

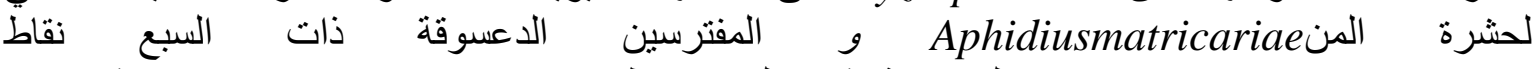
Coccinellaseptempunctata كفاءة نسب التطفل ونسب البزوغ ونسب الموت في بالغات الطفيل الداخلي ،اثر المبيد نيمكس على الثى حشرات من الخوخ الاخضر Myzuspersicae فبلغت نسب القتل فئل

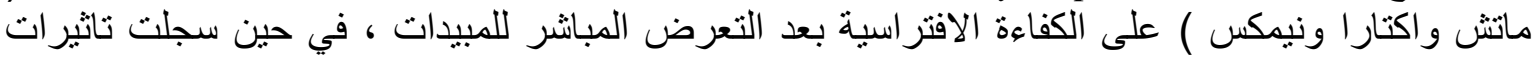

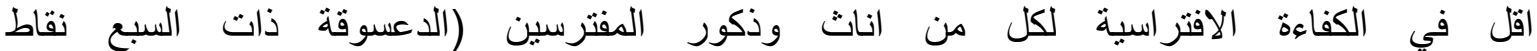

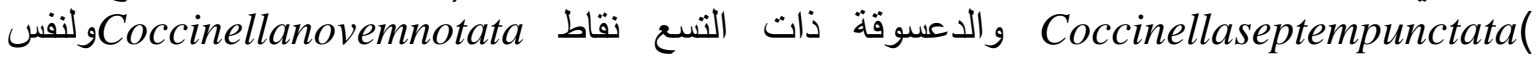
المبيدات عند العاملة غير المباشرة. الكلمات المفتاحية : الدعسوقة ذات السبع التبرة نقاط و الدعسوقة ذات التسع نقاط,المبيدات الحشرية (اكتار ا، ماتش، نيمكس).

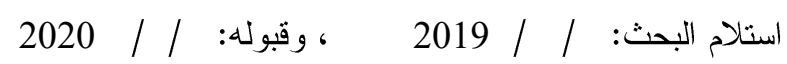

\section{REFERENCES}

Abdel-Wali, M. ; Mustafa,T. and Al-mazraawi, M.S.(2007). Toxicity of selected insecticides to green Aphid, Myzuspersicae (Homo.: Aphididae) and its 
parasitoid, Aphidiusmatricariae ( Hym.: Aphidiidae). American-Eurasian Journal of Agricultural and Environmental Sciences, 2(5):498-503

Abbott, W.S. (1925). A method of computing the effectiveness of an insecticides. Journal of Economic Entomology, 18 : 265-267.

Al-Mallah, Nizar Mustafa and Fahd Abdo Al-Mikhlafi (2005). The effect of trigard insect growth inhibitor and the type of food host on some biometrics of the Southern Cowpea Beetle. Tech Magazine, 36: 18_45.

Al-Mallah, Nizar Mustafa and JuhinaAdrees Muhammad Ali (2007). The complementarity between the insect growth inhibitor Trigard and the sevenpoint ladybird in the fight against black beans. Mesopotamia Journal of Agriculture,35 (3): 139-144>

Anonymous, (2002). SAS. The Statistical Analysis System. SAS Institute, CARY, NC, USA.

BaozhuZhong, ChaojunLv, and Weiquan Qin(2017). "Effectiveness of the botanical insecticide

Azadirachtinagainst Tirathabarufivena (Lepidoptera: Pyralidae). Florida Entomologist 100(2), 215-218.

Fuentes-Contreras, E. ; Basoalto, E.; Sandoval, C.; Pavez1,P.; Leal1,C.; and CristianMuonz, R.B.(2007). Evaluation of efficacy, residual and knock down effects of pretransplant applications of nicotinoid and nicotinoid-pyrethroid insecticide mixtures for the control of Myzuspersicaenicotianae (Hemiptera: Aphididae) on tobacco.AgriculturaTecnica (chile) 67(1):16-22

ZanuncioJ C, Abreu M, Luis C, Martínez, C Frederico W, Francisco S. Ramalho, Angelica Plata-R, Marcus. A, and José Eduardo S (2016) .Toxic effects of the neem oil (Azadirachtaindica) formulation on the stink bug predator, Podisusnigrispinus (Heteroptera: Pentatomidae). Sci. Rep., 6: 30261.

Palumbo,J.C. (2011). Assessment of insect losses and insecticide use on Arizona head lettuce, 2004-2010 . Yuma agricultural center, UavegIpm Update, 2, (8).

Palumbo,J.C, Al Fournier,K.N. and Ellsworth,P (2008). Insect Crop Losses and Insecticide Usage for Head Lettuce in Arizona: 2006/2007. Vegetable Report (P152):86-95

Saljoqi, A.U.R. and Van Emdem,H.F.(2003). Differential susceptibilities of peachpotato aphid, Myzuspersicae (Homoptera: Aphididae) and its parasitoid, Aphidiusmatricariae (Hymenoptera:Aphidiidae) to foliar insecticides on partially resistant and susceptible potato cultivars . Pakistan Journal of biological science, 6(4) 386- 393.

Sheet, J. J., Karr, L. L. and Dripps, J. E.(2000). Kinetics of uptake, clearance, transfer and metabolism of match by eastern subterranean termites (Isoptera: Rhinotermitidae). Journal Of Economic Entomology, 93(3): 871-877.

Silva, A.X., G. Jander, H. Samaniego, J.S. Ramsey, and C.C. Figueroa (2012). Insecticide Resistance Mechanisms in The Green Peach Aphid Myzuspersicae (Hemiptera: Aphididae) I: A Transcriptomic Survey. PLos One, 7(6):e36366. (doi:10.1371/ .0036366). 